\title{
Role of the high mobility group A proteins in the regulation of pituitary cell cycle
}

\author{
Monica Fedele ${ }^{1,2}$ and Alfredo Fusco ${ }^{1,2}$ \\ ${ }^{1}$ Istituto di Endocrinologia ed Oncologia Sperimentale (IEOS) del CNR, 80131 Naples, Italy \\ ${ }^{2}$ Dipartimento di Biologia e Patologia Cellulare e Molecolare, Università degli Studi di Napoli ‘Federico II', 80131 Naples, Italy \\ (Correspondence should be addressed to M Fedele at Dipartimento di Biologia e Patologia Cellulare e Molecolare, Istituto di Endocrinologia ed Oncologia \\ Sperimentale (IEOS) del CNR, Università degli Studi di Napoli ‘Federico II’; Email: mfedele @ unina.it)
}

\begin{abstract}
Pituitary cells are particularly sensitive to alterations of the cell cycle machinery. In fact, mutations affecting expression of proteins critical for cell cycle progression, including retinoblastoma protein, cyclins D1 and D3, p16 ${ }^{\mathrm{INK} 4 \mathrm{~A}}$, and p27 ${ }^{\mathrm{kip} 1}$, are frequent in human pituitary adenomas. Similarly, both targeted disruption and overexpression of either cell cycle inhibitors or activators, respectively, lead to the development of pituitary adenomas in mice. Recent evidence has added the high mobility group A (HMGA) proteins as a new class of cell cycle regulators that play significant roles in the pathways that lead to pituitary tumor evolution in both humans and experimental animal models. Here, we first review the role of the cell cycle in pituitary tumorigenesis, as witnessed by human pathology and transgenic mice; and then, we focus on HMGA proteins and their cell cycle-related role in pituitary tumorigenesis.
\end{abstract}

Journal of Molecular Endocrinology (2010) 44, 309-318

\section{Introduction}

The pituitary gland is a critical endocrine organ on which growth, metabolism, reproduction, and homeostasis depend. In mammals, it consists of three lobes: the anterior and the intermediate lobes form the adenohypophysis, while the posterior lobe represents the neurohypophysis. The adenohypophysis secretes seven different hormones: GH, TSH, prolactin (PRL), FSH, LH, ACTH, and melanocyte-stimulating hormone, whereas the neurohypophysis releases two hypothalamic neuropeptides, vasopressin and oxytocin. In the adenohypophysis, hormones are produced by different cell types, whose absolute and relative number may vary during adult life depending on the endocrine demands (Sasaki 1988, Levy 2002). The regulation of the proliferative ability of pituitary cells in adulthood is not well established, although the presence of a side population of stem/progenitor cells, which may contribute to cell renewal in the adult pituitary, has been described (Chen et al. 2005, 2009). Recent experimental data suggest that cell cycle regulators may have significant implications in the biology of putative progenitor cells and pituitary homeostasis (Janzen et al. 2006, Macias et al. 2008). Indeed, cell cycle plays a key role in the development of pituitary adenomas as assessed in humans and mice.

\section{The cell cycle}

The cell cycle is the process by which cells divide into daughter cells. It comprises a defined sequence of events, which include: synthesis of DNA (S phase), mitosis ( $\mathrm{M}$ phase), and two phases of growing and preparation for following steps $\left(G_{1}\right.$ and $G_{2}$ phases; Fig. 1). A reversible quiescence phase $\left(G_{0}\right)$, in which cells 'take a rest' in the absence of mitogenic signals, is also considered part of the cell cycle (Norbury \& Nurse 1992). At particular stages of the cell cycle, cells encounter a restriction point and four checkpoints that enable the correct progress and completion of each cycle. The restriction point $(R)$ is a specific molecular event, which is set between early and late $\mathrm{G}_{1}$ phases, after which cells can proliferate independently from mitogenic stimuli (Pardee 1974), whereas checkpoints are surveillance mechanisms and quality controls of the genome to maintain genomic integrity, which are set between $G_{1}$ and $S$, intra-S, between $G_{2}$ and $M$ and intra-M (Hartwell \& Weinert 1989).

DOI: 10.1677/JME-09-0178 Online version via http://www.endocrinology-journals.org 


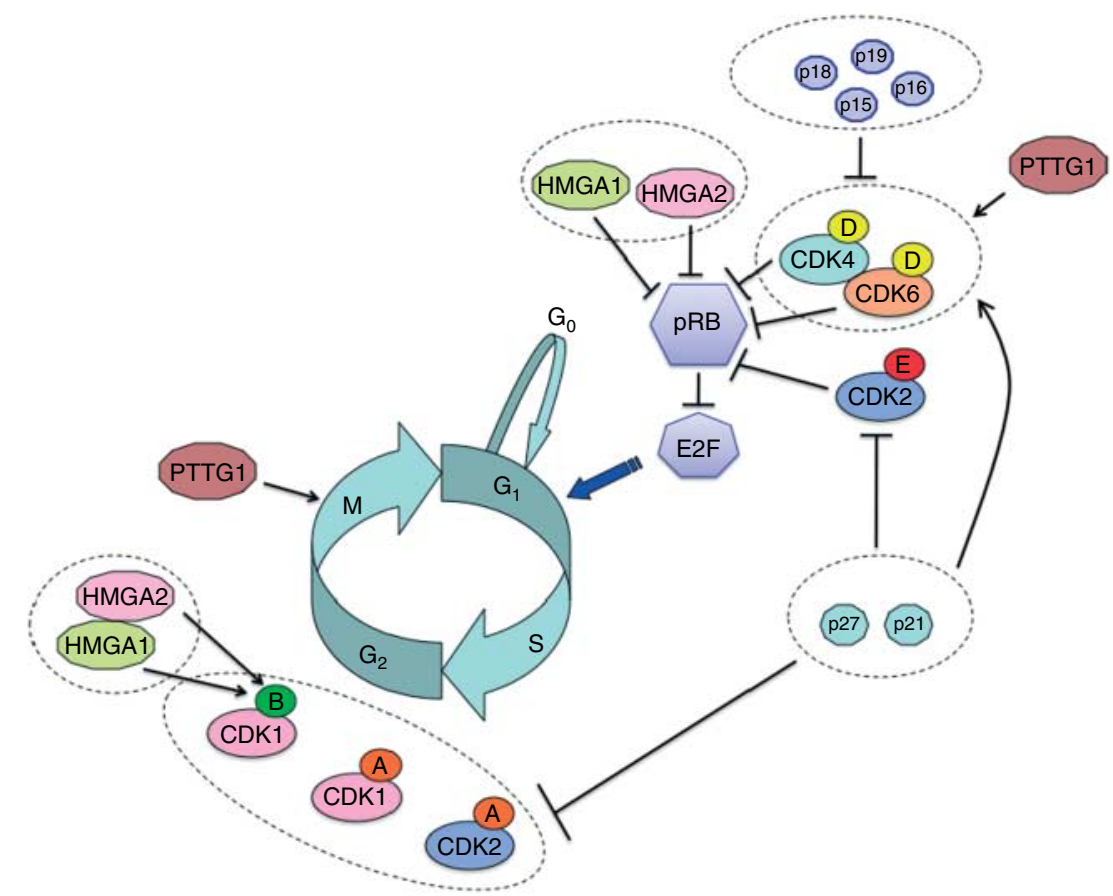

Figure 1 Schematic representation of the main cell cycle regulating pathways affected in pituitary tumors. The blue arrow indicates the restriction point. A, B, D, and $E$ define the different cyclins. Stimulatory or inhibitory effects are indicated by an arrow or a bar, respectively, at the end of a line. Dotted ovals indicate group proteins and protein complexes that share similar functions and regulations.

Both activating and inhibitory signals, represented by cyclins coupled to cyclin-dependent kinases (CDKs) and CDK inhibitors (CKI), respectively, finely regulate the progress of the cell through the different phases of the cell cycle (Morgan 1997, Vidal \& Koff 2000).

Among the activators, D-type cyclins, coupled to CDK4 and CDK6, promote the progression through $\mathrm{G}_{1}$; E-type cyclins, coupled to CDK2, are involved in the $\mathrm{G}_{1} / \mathrm{S}$ transition; A-type cyclins, coupled to CDK2 and $\mathrm{CDK} 1$, participate in the $\mathrm{S} / \mathrm{G}_{2}$ transition and progression through $\mathrm{G}_{2}$ respectively; B-type cyclins, coupled to $\mathrm{CDK} 1$, are involved in the $\mathrm{G}_{2} / \mathrm{M}$ transition; cyclins A and B also complex with CDK1/CDC2/p34 to form the mitosis-promoting factor whose activity peaks at $\mathrm{G}_{2} / \mathrm{M}$ transition, being required for the cell to enter M phase (Pines \& Hunter 1989).

The transcription factor family E2F plays a critical role in $\mathrm{G}_{0} / \mathrm{G}_{1}, \mathrm{R}$, and $\mathrm{G}_{1} / \mathrm{S}$ transitions, by allowing transcription of D- and E-type cyclins. Consistently, the gatekeeper retinoblastoma protein $(\mathrm{pRB})$ negatively regulates $G_{1}$ entering, progression, and transition to $\mathrm{S}$ by blocking the activity of factors responsible for cell cycle progression, which include the E2Fs. CDK4, CDK6, and CDK2, complexed to D- and E-type cyclins, mediate phosphorylation of $\mathrm{pRB}$, thus provoking the release and activation of $\mathrm{E} 2 \mathrm{~F}$ factors from pRB (Fig. 1). The pRB/E2Fs complex can also be regulated by acetylation/deacetylation, mediated by histone acetylases and deacetylases (Magnaghi-Jaulin et al. 1998, Martínez-Bálbas et al. 2000).

The action of the cyclin-CDK complexes is counteracted by specific CKIs either by blocking the action of CDKs or by impairing substrate/ATP access. The CKIs belong to two families: the INK4 and the Cip/Kip families. The INK4 family consists of four members $\left(\mathrm{p} 16^{\mathrm{INK} 4 \mathrm{a}}, \mathrm{p} 15^{\mathrm{INK} 4 \mathrm{~b}}, \mathrm{p} 18^{\mathrm{INK} 4 \mathrm{c}}\right.$, and $\left.\mathrm{p} 19^{\mathrm{INK} 4 \mathrm{~d}}\right)$, which inhibit the $\mathrm{G}_{1} / \mathrm{S}$ transition by blocking CDK4 and CDK6. Conversely, the Cip/Kip family, which includes $\mathrm{p} 21^{\mathrm{Cip} 1}, \mathrm{p} 27^{\mathrm{Kip} 1}$, and $\mathrm{p} 57^{\mathrm{Kip} 2}$, has different roles depending on the cyclin-CDK complexes, which they bind to. Association with cyclin-CDK2 and cyclin-CDK1 blocks their activity, whereas binding to cyclin-CDK4 and cyclin-CDK6 can upregulate their activity (Cheng et al. 1999, Sherr \& Roberts 1999; Fig. 1).

Negative regulation of the cell cycle is not restricted to CKIs. One critical target of negative regulation that acts in M phase is a protein named securin or PTTG1 (Pei \& Melmed 1997). During metaphase, replicated paired sister chromatids are held together by the cohesin complex, which is degraded by the proteolytic protein separase, during the metaphase to anaphase transition, to allow the separation of sister chromatids to proceed to diploid daughter cells (Uhlmann et al. 1999). The activity of separase is inhibited by the 
interaction with securin, whose proteosomal degradation by the ubiquitin ligase APC is crucial for the completion of the anaphase process (Zou et al. 1999). In addition to this securin function, recent reports indicate a role for PTTG1 in modulation of the $\mathrm{G}_{1} / \mathrm{S}$ phase transition by interacting with $\mathrm{Sp} 1$ and regulating the transcriptional activity on the cyclin D3 promoter (Tong et al. 2007). Interestingly, securin/ PTTG1 is regulated by CDK1-mediated phosphorylation (Holt et al. 2008) suggesting a link between the control of the cell cycle by CDKs and securin function.

\section{Cell cycle dysregulation in human pituitary tumorigenesis}

Cell cycle dysregulation is the main pathogenetic event in the development of pituitary tumors. In fact, it has been estimated that more than $80 \%$ of human pituitary tumors display alterations at least in one of the regulators of the $G_{1} / S$ transition of the cell cycle (Malumbres \& Barbacid 2001; Table 1). These alterations are frequently represented by epigenetic events that target several cell cycle regulators, leading to overexpression of cyclins (mainly D1, D3, E, B1, and B2), as well as to downregulation of CKIs (mainly $\mathrm{p} 16^{\mathrm{INK} 4 \mathrm{~A}}, \mathrm{p} 15^{\mathrm{INK} 4 \mathrm{~B}}, \mathrm{p} 27^{\mathrm{Kip1}}$, and $\mathrm{p} 21^{\mathrm{Cip} 1}$ ) and $\mathrm{pRB}$ expression (Farrell \& Clayton 2003). Cyclins D1 and D3, as well as cyclin E, are frequently overexpressed in all subtypes of human pituitary adenomas, with prevalence in nonfunctional pituitary adenomas (NFPA) for the D-type ( Jordan et al. 2000, Turner et al. 2000, Saeger et al. 2001, Simpson et al. 2001) and in corticotroph tumors for the E-type cyclins ( Jordan et al. 2000). A cyclin D1 gene allelic imbalance has also been described in about $25 \%$ of analyzed adenomas (Hibberts et al. 1999). B-type cyclins have recently been described as overexpressed in many human pituitary adenomas, with prevalence in prolactinomas (Wierinckx et al. 2007, De Martino et al. 2009b). Silencing of the gene encoding $\mathrm{p} 16^{\mathrm{INK} 4 \mathrm{~A}}$ by methylation is frequent in pituitary, mainly NFPA (Woloschak et al. 1997, Simpson et al. 1999a, Morris et al. 2005, Ogino et al. 2005, Yoshino et al. 2007). Downregulation of $\mathrm{p} 27^{\mathrm{kip} 1}$ protein expression, likely due to a JAB1-mediated increased proteolysis (Korbonits et al. 2002), is frequent in pituitary carcinomas and ACTH-secreting adenomas (Bamberger et al. 1999, Lidhar et al. 1999). Conversely, downregulation of p21 ${ }^{\mathrm{Cip} 1}$ in pituitary adenomas may be due to epigenetic modifications (Yoshino et al. 2007, Zhu et al. 2008). Similarly, frequent loss of pRB expression observed in $27 \%$ of somatotrophinomas (Simpson et al. 1999b) was mainly due to methylation and/or microdeletion of the RB1 gene (Simpson et al. 2000).

In addition to these classical cell cycle-related proteins, the overexpression of PTTG1 has been observed in more than $90 \%$ of all types of pituitary tumors (Zhang et al. 1999). Finally, as described in more detail in a subsequent section of this review, overexpression of high mobility group A (HMGA) proteins has been shown to play a critical role in development of pituitary adenomas, mainly prolactinomas and GH/PRL-secreting adenomas, by mechanisms involving dysregulation of cell cycle-related proteins (Fedele et al. 2002, 2006, Finelli et al. 2002, De Martino et al. 2009b).

Table 1 Major cell cycle-related proteins altered in human pituitary tumors

Cell cycle transition

Protein

Cyclin D1

Cyclin D3

Cyclin E

Cyclin B1

Cyclin B2

p16 ${ }^{\text {INK4a }}$

p2 $7^{\text {Kip1 }}$

JAB1

p21 ${ }^{\text {Cip1 }}$

pRB

Securin

HMGA1/2

$\mathrm{G}_{1} / \mathrm{S}$
$\mathrm{G}_{1} / \mathrm{S}$
$\mathrm{G}_{1} / \mathrm{S}$
$\mathrm{G}_{2} / \mathrm{M}$
$\mathrm{G}_{2} / \mathrm{M}$
$\mathrm{G}_{1} / \mathrm{S}$
$\mathrm{G}_{1} / \mathrm{S}$
$\mathrm{G}_{1} / \mathrm{S}$
$\mathrm{G}_{1} / \mathrm{S}$
$\mathrm{G}_{1} / \mathrm{S}$

$\mathrm{G}_{1} / \mathrm{S}$ and $\mathrm{G}_{2} / \mathrm{M}$

$\mathrm{G}_{1} / \mathrm{S}$ and $\mathrm{G}_{2} / \mathrm{M}$
Pituitary tumor subtype

GH secreting
Nonfunctioning
All different types
ACTH secreting
Invasive PRL
Aggressive PRL
All different types
Nonfunctioning
Nonfunctioning
All different types
ACTH secreting
Carcinomas
Carcinomas
Nonfunctioning
Hormone secreting
GH secreting
GH secreting
All different types
All different types
All different types

Incidence (\%)

30

50

68

37

89

100

100

70

62

40

100

100

100

71

77

92

27

35

90

100
References

Simpson et al. (2001)

Simpson et al. (2001)

Saeger et al. (2001)

Jordan et al. (2000)

Wierinckx et al. (2007)

Wierinckx et al. (2007)

De Martino et al. (2009b)

Simpson et al. (1999a)

Machiavelli et al. (2008)

Machiavelli et al. (2008)

Lidhar et al. (1999)

Lidhar et al. (1999)

Korbonits et al. (2002)

Neto et al. (2005)

Neto et al. (2005)

Neto et al. (2005)

Simpson et al. (1999b)

Yoshino et al. (2007)

Zhang et al. (1999)

De Martino et al. (2009b) 


\section{Cell cycle-related mouse models of pituitary adenomas}

In keeping with the critical role of cell cycle dysregulation in pituitary tumorigenesis, targeted disruption or overexpression of cell cycle regulators frequently causes onset of pituitary adenomas (Table 2). The first mouse model of cell cycle-related pituitary tumorigenesis came from the phenotype of knockout mice for pRb (Jacks et al. 1992). The heterozygous animals developed pituitary tumors of the intermediate lobe (IL) arising from cells in which the wild-type $\mathrm{Rb}$ allele was absent. Loss of either E2F1 or E2F4 reduced pituitary tumorigenesis in these mice, suggesting that loss of $\mathrm{pRB}$ induces the onset of pituitary tumors by activating E2F factors (Yamasaki et al. 1998, Lee et al. 2002). Consistently, deregulated E2F activity in E2f3-transgenic mice induces hyperplasia of the pituitary gland (Lazzerini Denchi et al. 2005). Subsequently, three different groups reported the characterization of another mouse model of pituitary tumorigenesis: the knockout mice for p27 $7^{\text {kip1 }}$ (Fero et al. 1996, Kiyokawa et al. 1996, Nakayama et al. 1996). As in the pRb mutants, p2 $7^{\text {kip1 }}$-null mice develop pituitary adenomas involving IL melanotrophs, even though differences in terms of gene expression and tumor phenotypes have been observed between the two models (Chien et al. 2007).
Therefore, despite the fact that deletions of $\mathrm{p} 27^{\mathrm{Kip} 1}$ or $\mathrm{Rb}$ cause IL tumors in murine models, they may have different mechanisms of tumor suppression. Indeed, as already described above, in addition to cyclin D complexes, which act upstream of pRB, p27 $7^{\mathrm{Kip} 1}$ inhibits both Cdk1 and Cdk2, both of which are capable of phosphorylating substrates other than pRB (Fig. 1). Crossing of $\mathrm{pRb}^{+/-}$and ${\mathrm{p} 27^{-/-}}^{-}$mice lead to double mutants having a significantly reduced tumor latency period compared with single mutants (Park et al. 1999). Intriguingly, a recent new mouse model of pituitary tumorigenesis, the knock-in mice depleted of the Cdk inhibitory function of p27, develops pituitary adenomas larger and more vascular, causing more damage to surrounding tissue than those developing in p27-null mice (Besson et al. 2007). Interestingly, a recent study highlighted the importance of the mouse strain on pituitary tumor evolution, since it showed that $129 \mathrm{~Sv}$ animals are inherently predisposed to IL pituitary tumors and that $\mathrm{Rb}^{+/-}$mice in a C57BL/6 background develop high-penetrance anterior pituitary (AP) tumors (Leung et al. 2004).

Another Cdk inhibitor, p18 ${ }^{\text {ink4c }}$, has been shown to be crucial in the homeostasis of the pituitary cell cycle. In fact, $\mathrm{p} 18^{-/-}$mice develop pituitary adenomas in both intermediate and anterior lobes (Franklin et al. 1998). Interestingly, crossing of p18-null mice with mice

Table 2 Mouse models of pituitary tumorigenesis caused by cell cycle dysregulation

Pituitary phenotype

\section{Mice}

$\mathrm{pRb}^{+/-}$

(129/sv background) (C57BL/6 background) ER-E2f3 ${ }^{T G}$

p27 ${ }^{-1-}$

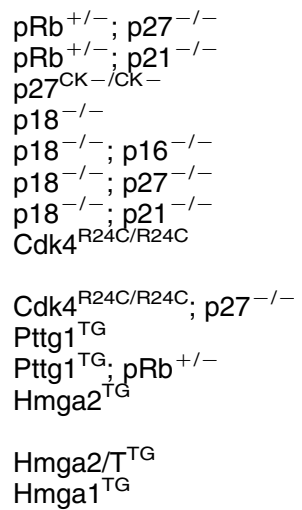

IL adenomas

IL adenomas

AP adenomas Hyperplasias IL adenomas

IL adenomas

IL adenomas

Aggress. AP adenomas

IL and AP adenomas

$\mathrm{IL}$ and AP adenomas

$\mathrm{IL}$ and AP adenomas

$\mathrm{IL}$ and $\mathrm{AP}$ adenomas

AP adenomas

Undiff. adenomas

Hyperplasias

IL and AP adenomas

AP adenomas

AP adenomas

AP adenomas

Incidence (\%) Latency (months)

References

$\begin{array}{lll}100 & 16 & \text { Jacks et al. (1992) } \\ 100 & 11 & \text { Brugarolas et al. (1998) } \\ 100 & 8 & \text { Lazzerini Denchi et al. (2005) } \\ 100 & 9 & \text { Leung et al. (2004) } \\ 70 & 12 & \text { Leung et al. (2004) } \\ 100 & 3 & \text { Lazzerini Denchi et al. (2005) } \\ 100 & 7 & \text { Kiyokawa et al. (1996) } \\ 100 & 2 & \text { Fero et al. (1996) } \\ 50 & 3 & \text { Nakayama et al. (1996) } \\ 90 & 7 & \text { Park et al. (1999) } \\ 100 & 9 & \text { Brugarolas et al. (1998) } \\ 100 & 6 & \text { Besson et al. (2007) } \\ 50 & 15 & \text { Franklin et al. (2000) } \\ & 10 & \text { Ramsey et al. (2007) } \\ 100 & 3 & \text { Franklin et al. (1998) } \\ 90 & 13 & \text { Franklin et al. (2000) } \\ 25 & 15 & \text { Rane et al. (2002) } \\ 22 & 15 & \text { Sotillo et al. (2001) } \\ 100 & 2 & \text { Sotillo et al. (2005) } \\ 100 & 4 & \text { Donangelo et al. (2006) } \\ 100 & 11 & \text { Donangelo et al. (2006) } \\ 85 \text { (females) } & 6 \text { (females) } & \text { Fedele et al. (2002) } \\ 40 \text { (males) } & 18 \text { (males) } & \text { Fedele et al. (2002) } \\ 100 \text { (females) } & 6 \text { (females) } & \text { Fedele M (unpublished data) } \\ 80 \text { (females) } & 12 \text { (females) } & \text { Fedele et al. (2005) } \\ 15 \text { (males) } & 16 \text { (males) } & \text { Fedele et al. (2005) } \\ & & \end{array}$


deficient for other Cdk inhibitors, such as p16, p27, or p21, led to double mutant mice with increased incidence and decreased latency in the development of pituitary adenomas as compared with single mutant mice (Franklin et al. 1998, 2000, Ramsey et al. 2007). Therefore, the existence of two major pathways for $\mathrm{G}_{1} / \mathrm{S}$ phase dysregulation in pituitary tumors has been suggested: one involving $\mathrm{p} 18 / \mathrm{CDK} 4 / \mathrm{pRB}$, and the other one involving p27 and p21 (Quereda \& Malumbres 2009). Consistently, knock-in mice, which express a Cdk4 mutant originally found in human melanoma (Wölfel et al. 1995) and which are insensitive to INK4 inhibitors (Cdk4 R24C), develop several tumors, including pituitary adenomas (Sotillo et al. 2001, Rane et al. 2002). Crossing of Cdk4 ${ }^{\mathrm{R} 24 \mathrm{C} / \mathrm{R} 24 \mathrm{C}}$ mice with mice deficient for $\mathrm{p} 27$ (but not with those deficient for p18) generates mice that develop pituitary adenomas with higher incidence and shorter latency than compound Cdk4 knock-in mice (Sotillo et al. 2005). Moreover, a dramatic cooperation in pituitary tumor development has been observed in mutant mice carrying a combination of the Cdk4 R24C, p21-null, and p27-null alleles (Quereda \& Malumbres 2009).

Another protein involved in cell cycle regulation at different stages, and critical in pituitary alterations in mice, is PTTG1/securin. Indeed, transgenic mice overexpressing Pttg1 in the pituitary develop pituitary hyperplasia and focal microadenomas. Moreover, their crossing with $\mathrm{pRb}^{+/-}$mice led to the development of AP adenomas (Donangelo et al. 2006), whereas Pttg1 deletion results in pituitary p21 induction and abrogates tumor development in $\mathrm{Rb}^{+/-}$mice (Chesnokova et al. 2008).

Finally, mice overexpressing either members of the Hmga family (Hmgal and Hmga2), or the truncated mutant Hmga2 (Battista et al. 1999), develop large and hypervascular AP adenomas (Fedele et al. 2002, 2005). These proteins play key roles in a wide range of biological processes including regulation of cell cycle (see below).

\section{The HMGA proteins}

The HMGA protein family includes HMGAla and HMGA1b, which are encoded by the HMGA1 gene through an alternative splicing (Johnson et al. 1989), and the closely related HMGA2 protein (Manfioletti et al. 1991).

The HMGA1a, HMGA1b, and HMGA2 proteins are composed of 107, 96, and 108 amino acid residues respectively. Each of them contains three basic domains, named AT-hooks, through which they bind DNA in AT-rich regions inside the minor groove (Elton et al. 1987, Reeves \& Nissen 1990), and an acidic carboxy-terminal region, which contains several hydroxylic amino acids that are phosphorylated by casein kinase II. These proteins play key roles in chromatin architecture and gene expression control by serving as generalized chromatin modifiers, either enhancing or suppressing the ability of several transcriptional factors to act on transcriptional regulation (Thanos \& Maniatis 1995).

Both HMGA genes are widely expressed during embryogenesis, whereas they are absent or low expressed in adult cells and tissues (Zhou et al. 1995, Chiappetta et al. 1996, Rommel et al. 1997, Anand \& Chada 2000). Recently, it has been shown that HMGA2 is highly expressed in neural fetal and young adult stem cells, being required for its self-renewal, relative to old adult stem cells, by negatively regulating $p 16^{I n 4 a}$ and $p 19^{\text {Arf }}$ expression in fetal and young adult, but not in old adult, stages (Nishino et al. 2008).

HMGA overexpression represents a common feature of malignant neoplasias and a poor prognostic index since it often correlates with the presence of metastases and with a reduced survival (Fusco \& Fedele 2007). The HMGA genes have a critical role also in the development of benign tumors of mesenchymal origin including lipomas. In fact, rearrangements of the HMGA2 gene, due to 12q13-15 chromosomal translocations, have been frequently detected in these tumors (Ashar et al. 1995, Schoenmakers et al. 1995). In most of these cases, the HMGA2 modifications comprise truncation of the gene with the loss of the sequences coding for the C-tail and the 3'-UTR regulatory region that contains multiple target sites for let-7, one of the founding members of the microRNA (miR) family (Lee \& Dutta 2007, Mayr et al. 2007). Therefore, this truncation would result in HMGA2 overexpression due to the lack of the inhibitory effect by let-7.

As far as HMGA1 is concerned, chromosomal breakpoints causing rearrangements have not been found intragenically but are found either upstream or downstream of the HMGAl gene, and sometimes within an $80 \mathrm{~kb}$ surrounding region (Kazmierczak et al. 1996, 1998).

Different studies, both in vitro and in vivo, have demonstrated that overexpression of the HMGA proteins is a necessary event in cell transformation: a) the block of HMGA1 protein synthesis by an antisense methodology prevents rat thyroid malignant cell transformation by acute murine retroviruses (Berlingieri et al. 1995, 2002); b) a recombinant adenovirus carrying HMGA1 sequences in an antisense orientation, and able to suppress HMGA1 protein synthesis, induces cell death in two human thyroid anaplastic carcinoma cell lines, but not in normal thyroid cells (Scala et al. 2000); c) increased expression of both HMGA1 and HMGA2 proteins leads to neoplastic transformation of Ratla fibroblasts with anchorage-independent cell growth (Wood et al. 2000); d) shRNA-mediated HMGA1 silencing on lung and pancreatic carcinomas resulted in significant reductions in anchorage-independent proliferation in 
soft agar (Liau et al. 2007); and e) transgenic mice overexpressing either the Hmgal or Hmga2 gene, under the transcriptional control of different promoters, develop several neoplasias including abdominal/ pelvic lipomatosis, lipomas, mixed GH/PRL-secreting pituitary adenomas (Battista et al. 1999, Arlotta et al. 2000, Fedele et al. 2002), fibroadenomas of the breast, salivary gland adenomas (Zaidi et al. 2006), and mature T-cell lymphomas (Baldassarre et al. 2001, $\mathrm{Xu}$ et al. 2004).

\section{HMGA proteins in pituitary tumorigenesis}

Several pieces of evidence support a critical role of HMGA2 overexpression in the development of pituitary adenomas, particularly in prolactinomas that represent the most frequent histotype. Indeed, by dual-color interphase fluorescence in situ hybridization analysis using HMGA2-specific PACs and BACs, it was found that the HMGA2 locus was amplified in seven of the eight prolactinoma samples examined. The cytogenetic manifestations of elevated HMGA2 concentrations ranged from simple trisomy to tetrasomy of 12 and der(12) chromosomes to marker chromosomes bearing 12q14-15-derived regions (where the HMGA2 gene is located). Reverse transcription PCR, western blot, and immunohistochemical analysis showed HMGA2 overexpression in prolactinomas bearing rearrangement of regions 12q14-15 (Finelli et al. 2002). Conversely, the role of HMGA2 in development of NFPA is less evident since even though HMGA2 overexpression was observed in 12 out of 18 samples analyzed, the upregulation of the gene could be associated with amplification and/or rearrangement of the HMGA2 locus only in two cases (Pierantoni et al. 2005). Recently, HMGA2 expression has been analyzed using immunohistochemistry with respect to various clinicopathologic factors in 98 pituitary adenomas (Qian et al. 2009). Overexpression of HMGA2 was observed in 39\% of pituitary adenomas compared with normal adenohypophyseal tissue, and it was frequently found in PRL-, ACTH-, or FSH/LH-secreting adenomas and in NFPA, but relatively rare in $\mathrm{GH}-$ and mixed $\mathrm{GH} /$ PRL-secreting adenomas. HMGA2 expression was significantly associated with tumor invasion and was significantly higher in grade IV than in grades I, II, and III adenomas (Qian et al. 2009).

The amplification of the HMGA2 locus mainly accounts for HMGA2 overexpression at least in prolactinomas. However, it is likely that increased dosage of chromosome 12 is insufficient to drive up activation of the $H M G A 2$ gene, since it was found in NFPAs either expressing or not expressing the HMGA2 gene. Recent studies support the idea that decreased expression of miRs, able to modulate HMGA protein levels, may partially account for the abundant HMGA2 protein levels in pituitary adenomas. Indeed, decreased expression of let-7 was observed in 23 of $55(42 \%)$ adenomas with an inverse correlation between let-7 and HMGA2 expressions (Qian et al. 2009). Moreover, it has been shown that miRs 15, 16, and 196, which target the HMGA mRNAs (De Martino et al. 2009a, Kaddar et al. 2009, Palmieri et al. manuscript in preparation), are downregulated in human prolactinomas (Bottoni et al. 2005, Palmieri et al. manuscript in preparation).

The critical role of HMGA2 protein in pituitary oncogenesis is validated by the phenotype of transgenic mice overexpressing a truncated or a wild-type Hmga2 gene under the transcriptional control of the strong and ubiquitous CMV promoter (Fedele et al. 2002). In fact, most of these mice (85\% of females and $40 \%$ of males) showed the onset of pituitary adenomas secreting PRL and GH (Fedele et al. 2002).

Differently from HMGA2, the causal role of HMGA1 gene in pituitary carcinogenesis is still to be defined. In fact, even though both HMGA1 and HMGA2 transcripts have been found upregulated in a panel of 45 human pituitary adenomas (De Martino et al. 2009b), and transgenic mice overexpressing Hmgal develop pituitary adenomas secreting PRL and GH (Fedele et al. 2005), no rearrangements of the HMGA1 locus have been found. Moreover, the detection of HMGA1 overexpression in all pituitary adenomas subtypes seems to indicate that HMGAl induction may represent a secondary event in the tumorigenesis of pituitary gland.

\section{HMGA2 and the pituitary cell cycle}

Recent pieces of evidence indicate that HMGA2 protein is involved in the development of pituitary adenomas by interfering with the cell cycle machinery. Indeed, it has been demonstrated in the mouse model of Hmga2 transgenic mice that the positive role of HMGA2 in pituitary cell proliferation is due to the interaction with the RB-E2F pathway, suggesting a new class of cell cycle-related proteins: the suppressors of the cell cycle inhibitors (Fedele et al. 2006). In more detail, HMGA2 binds to $\mathrm{pRB} A / \mathrm{B}$ pocket domain thereby displacing the HDAC1 protein from pRB. This displacement results in the recruitment of HDAC to the E2F1 target promoters and acetylation of both histones and other proteins including E2F1. The acetylation of histones opens up the chromatin and facilitates gene transcription. Moreover, acetylation of E2F1 augments its DNA binding and stabilizes the protein in its free active form, thereby enhancing the expression of the E2F target genes, such as CDC6 and TK1 that promote the $\mathrm{G}_{1} / \mathrm{S}$ transition. The crucial role of enhanced E2F1 activity in 
the onset and progression of pituitary adenomas was validated by the rescue of the adenomatous phenotype when transgenic mice overexpressing the Hmga2 gene were mated with E2f1 knockout mice. In fact, the majority of double mutant mice did not develop tumors, and only a few of them showed small and slow growing adenomas (Fedele et al. 2006).

The alteration of cell cycle as a critical event in the induction of pituitary adenomas by the HMGA2 gene seems further confirmed by the direct role of HMGA proteins in the upregulation of cyclin B2 gene transcription, leading to overexpression of cyclin B2 in pituitary adenomas developed by mice carrying Hmga transgenes (De Martino et al. 2009b). Consistently, an increased expression of CCNB2, the human gene coding for the cyclin $\mathrm{B} 2$ protein, directly correlates with $H M G A 1$ and HMGA2 expression in human pituitary adenomas of different histotypes (De Martino et al. 2009b). Since cyclin B2, complexed with CDK1, plays a critical role in regulating the $\mathrm{G}_{2} / \mathrm{M}$ phase transition of the cell cycle, it is reasonable to hypothesize that cyclin B2 induction by HMGA proteins may contribute to increase cell proliferation of the pituitary cells where HMGA proteins are overexpressed. Interestingly, the analysis of the mRNA expression profile of the pituitary adenomas arising in Hmga transgenic mice also revealed the overexpression of other genes, such as Ccnb1, Ccnd3, and $C d c 2$, coding for proteins involved in cell cycle regulation (De Martino et al. 2007). It is likely that their altered expression may have a role in experimental and human pituitary neoplasias. However, further studies are required to define the role of these proteins in pituitary tumorigenesis.

\section{Concluding remarks}

In conclusion, these recent findings provide new insight with respect to the mechanisms that dysregulate the cell cycle in pituitary tumorigenesis. By acting as regulators of different steps of cell cycle progression, the HMGA proteins play a crucial role in the maintenance of the pituitary cell homeostasis. In fact, overexpression of HMGA proteins in mice is sufficient to get a pituitary phenotype only comparable to that observed by the cooperation of two genetic alterations affecting different cell cycle regulators. Also, it is possible that other mechanisms may contribute to the role of HMGA2 in pituitary tumorigenesis, consistent with the ability of HMGA proteins to either activate or repress many different genes.

Since the role of the HMGA2 overexpression represents a critical event in the development of a significant number of prolactinomas, a therapy based on the suppression of the HMGA2 function may be envisaged for the treatment of recurrent prolactinomas. However, as cell cycle alterations can arise independently from the event that has caused them, and they are crucial in pituitary tumorigenesis, therapies aimed to target cell cycle actors may be also conceived. Even not taking into account of the role of HMGA proteins in pituitary cell cycle, transgenic mice overexpressing either Hmgal or Hmga2 may be considered excellent animal models to explore new therapies for pituitary adenomas (Fedele et al. 2007).

\section{Declaration of interest}

The authors declare that there is no conflict of interest that could be perceived as prejudicing the impartiality of the research reported.

\section{Funding}

The authors are supported by grants from Associazione Italiana Ricerca sul Cancro (AIRC) and Programmi di Ricerca Scientifica di Rilevante Interesse Nazionale (PRIN).

\section{Acknowledgements}

M Fedele thanks R Visone, I De Martino, and D Palmieri for their outstanding contribute, during the years, on pituitary work.

\section{References}

Anand A \& Chada K 2000 In vivo modulation of Hmgic reduces obesity. Nature Genetics 24 377-380.

Arlotta P, Tai AK, Manfioletti G, Clifford C, Jay G \& Ono SJ 2000 Transgenic mice expressing a truncated form of the high mobility group I-C protein develop adiposity and an abnormally high prevalence of lipomas. Journal of Biological Chemistry $\mathbf{2 7 5}$ 14394-14400.

Ashar HR, Fejzo MS, Tkachenko A, Zhou X, Fletcher JA, Weremowicz S, Morton CC \& Chada K 1995 Disruption of the architectural factor HMGI-C: DNA-binding AT hook motifs fused in lipomas to distinct transcriptional regulatory domains. Cell 82 57-65.

Baldassarre G, Fedele M, Battista S, Vecchione A, Klein-Szanto AJ, Santoro M, Waldmann S, Azimi N, Croce CM \& Fusco A 2001 Onset of natural killer cell lymphomas in transgenic mice carrying a truncated HMGI-C gene by the chronic stimulation of the IL-2 and IL-15 pathway. PNAS 98 7970-7975.

Bamberger CM, Fehn M, Bamberger AM, Lüdecke DK, Beil FU, Saeger W \& Schulte HM 1999 Reduced expression levels of the cell-cycle inhibitor p2 $7^{\mathrm{Kip} 1}$ in human pituitary adenomas. European Journal of Endocrinology 140 250-255.

Battista S, Fidanza V, Fedele M, Klein-Szanto AJ, Outwater E, Brunner H, Santoro M, Croce CM \& Fusco A 1999 The expression of a truncated HMGI-C gene induces gigantism associated with lipomatosis. Cancer Research 59 4793-4797.

Berlingieri MT, Manfioletti G, Santoro M, Bandiera A, Visconti R, Giancotti V \& Fusco A 1995 Inhibition of HMGI-C protein synthesis suppresses retrovirally induced neoplastic transformation of rat thyroid cells. Molecular and Cellular Biology 15 1545-1553.

Berlingieri MT, Pierantoni GM, Giancotti V, Santoro M \& Fusco A 2002 Thyroid cell transformation requires the expression of the HMGA1 proteins. Oncogene 21 2971-2980. 
Besson A, Hwang HC, Cicero S, Donovan SL, Gurian-West M, Johnson D, Clurman BE, Dyer MA \& Roberts JM 2007 Discovery of an oncogenic activity in $\mathrm{p} 27^{\mathrm{Kip} 1}$ that causes stem cell expansion and a multiple tumor phenotype. Genes and Development 21 1731-1746.

Bottoni A, Piccin D, Tagliati F, Luchin A, Zatelli MC \& degli Uberti EC 2005 miR-15a and miR-16-1 down-regulation in pituitary adenomas. Journal of Cellular Physiology 204 280-285.

Brugarolas J, Bronson RT \& Jacks T 1998 p21 is a critical CDK2 regulator essential for proliferation control in $\mathrm{Rb}$-deficient cells. Journal of Cell Biology 141 503-514.

Chen J, Hersmus N, Van Duppen V, Caesens P, Denef C \& Vankelecom H 2005 The adult pituitary contains a cell population displaying stem/progenitor cell and early embryonic characteristics. Endocrinology 146 3985-3998.

Chen J, Gremeaux L, Fu Q, Liekens D, Van Laere S \& Vankelecom H 2009 Pituitary progenitor cells tracked down by side population dissection. Stem Cells 27 1182-1195.

Cheng M, Olivier P, Diehl JA, Fero M, Roussel MF, Roberts JM \& Sherr CJ 1999 The p21(Cip1) and p27(Kip1) CDK 'inhibitors' are essential activators of cyclin D-dependent kinases in murine fibroblasts. EMBO Journal 18 1571-1583.

Chesnokova V, Zonis S, Kovacs K, Ben-Shlomo A, Wawrowsky K, Bannykh S \& Melmed S 2008 p21(Cip1) restrains pituitary tumor growth. PNAS 105 17498-17503.

Chiappetta G, Avantaggiato V, Visconti R, Fedele M, Battista S, Trapasso F, Merciai BM, Fidanza V, Giancotti V, Santoro M et al. 1996 High level expression of the HMGI (Y) gene during embryonic development. Oncogene 13 2439-2446.

Chien WM, Garrison K, Caufield E, Orthel J, Dill J \& Fero ML 2007 Differential gene expression of $\mathrm{p} 27^{\mathrm{Kip} 1}$ and Rb knockout pituitary tumors associated with altered growth and angiogenesis. Cell Cycle $\mathbf{6}$ $750-757$.

De Martino I, Visone R, Fedele M, Petrocca F, Palmieri D, Martinez Hoyos J, Forzati F, Croce CM \& Fusco A $2009 a$ Regulation of microRNA expression by HMGA1 proteins. Oncogene 28 1432-1442.

De Martino I, Visone R, Wierinckx A, Palmieri D, Ferraro A, Cappabianca P, Chiappetta G, Forzati F, Lombardi G, Colao A et al. $2009 b$ HMGA proteins up-regulate CCNB2 gene in mouse and human pituitary adenomas. Cancer Research 69 1844-1850.

Donangelo I, Gutman S, Horvath E, Kovacs K, Wawrowsky K, Mount M \& Melmed S 2006 Pituitary tumor transforming gene overexpression facilitates pituitary tumor development. Endocrinology 147 4781-4791.

Elton TS, Nissen MS \& Reeves R 1987 Specific A.T DNA sequence binding of RP-HPLC purified HMG-I. Biochemical and Biophysical Research Communications 143 260-265.

Farrell WE \& Clayton RN 2003 Epigenetic change in pituitary tumorigenesis. Endocrine-Related Cancer 10 323-330.

Fedele M, Battista S, Kenyon L, Baldassarre G, Fidanza V, Klein-Szanto AJ, Parlow AF, Visone R, Pierantoni GM, Outwater E et al. 2002 Overexpression of the HMGA2 gene in transgenic mice leads to the onset of pituitary adenomas. Oncogene 21 3190-3198.

Fedele M, Pentimalli F, Baldassarre G, Battista S, Klein-Szanto AJ, Kenyon L, Visone R, De Martino I, Ciarmiello A, Arra C et al. 2005 Transgenic mice overexpressing the wild-type form of the HMGA1 gene develop mixed growth hormone/prolactin cell pituitary adenomas and natural killer cell lymphomas. Oncogene $\mathbf{2 4}$ $3427-3435$.

Fedele M, Visone R, De Martino I, Troncone G, Palmieri D, Battista S, Ciarmiello A, Pallante P, Arra C, Melillo RM et al. 2006 HMGA2 induces pituitary tumorigenesis by enhancing E2F1 activity. Cancer Cell 9 459-471.

Fedele M, De Martino I, Pivonello R, Ciarmiello A, Del Basso De Caro ML, Visone R, Palmieri D, Pierantoni GM, Arra C, Schmid HA et al. 2007 SOM230, a new somatostatin analogue, is highly effective in the therapy of growth hormone/prolactinsecreting pituitary adenomas. Clinical Cancer Research 13 2738-2744.
Fero ML, Rivkin M, Tasch M, Porter P, Carow CE, Firpo E, Polyak K, Tsai LH, Broudy V, Perlmutter RM et al. 1996 A syndrome of multiorgan hyperplasia with features of gigantism, tumorigenesis, and female sterility in p27(Kip1)-deficient mice. Cell 85 733-744.

Finelli P, Pierantoni GM, Giardino D, Losa M, Rodeschini O, Fedele M, Valtorta E, Mortini P, Croce CM, Larizza L et al. 2002 The high mobility group A2 gene is amplified and overexpressed in human prolactinomas. Cancer Research 62 2398-2405.

Franklin DS, Godfrey VL, Lee H, Kovalev GI, Schoonhoven R, Chen-Kiang S, Su L \& Xiong Y 1998 CDK inhibitors p18(INK4c) and p27(Kip1) mediate two separate pathways to collaboratively suppress pituitary tumorigenesis. Genes and Development 12 2899-2911.

Franklin DS, Godfrey VL, O'Brien DA, Deng C \& Xiong Y 2000 Functional collaboration between different cyclin-dependent kinase inhibitors suppresses tumor growth with distinct tissue specificity. Molecular and Cellular Biology 20 6147-6158.

Fusco A \& Fedele M 2007 Roles of HMGA proteins in cancer. Nature Reviews. Cancer 7 899-910.

Hartwell LH \& Weinert TA 1989 Checkpoints: controls that ensure the order of cell cycle events. Science 246 629-634.

Hibberts NA, Simpson DJ, Bicknell JE, Broome JC, Hoban PR, Clayton RN \& Farrell WE 1999 Analysis of cyclin D1 (CCND1) allelic imbalance and overexpression in sporadic human pituitary tumors. Clinical Cancer Research 5 2133-2139.

Holt LJ, Krutchinsky AN \& Morgan DO 2008 Positive feedback sharpens the anaphase switch. Nature 454 353-357.

Jacks T, Fazeli A, Schmitt EM, Bronson RT, Goodell MA \& Weinberg RA 1992 Effects of an $\mathrm{Rb}$ mutation in the mouse. Nature $\mathbf{3 5 9}$ 295-300.

Janzen V, Forkert R, Fleming HE, Saito Y, Waring MT, Dombkowski DM, Cheng T, DePinho RA, Sharpless NE \& Scadden DT 2006 Stem-cell ageing modified by the cyclin-dependent kinase inhibitor p16 $6^{\text {INK4a }}$. Nature 443 421-426.

Johnson KR, Lehn DA \& Reeves R 1989 Alternative processing of mRNAs encoding mammalian chromosomal high- mobility-group proteins HMG-I and HMG-Y. Molecular and Cellular Biology 9 2114-2123.

Jordan S, Lidhar K, Korbonits M, Lowe DG \& Grossman AB 2000 Cyclin D and cyclin E expression in normal and adenomatous pituitary. European Journal of Endocrinology 143 R1-R6.

Kaddar T, Rouault JP, Chien WW, Chebel A, Gadoux M, Salles G, Ffrench M \& Magaud JP 2009 Two new miR-16 targets: caprin-1 and HMGA1, proteins implicated in cell proliferation. Biology of the Cell 101 511-524.

Kazmierczak B, Wanschura S, Rommel B, Bartnitzke S \& Bullerdiek J 1996 Ten pulmonary chondroid hamartomas with chromosome 6p21 breakpoints within the HMG-I(Y) gene or its immediate surroundings. Journal of the National Cancer Institute 88 1234-1236.

Kazmierczak B, Dal Cin P, Wanschura S, Borrmann L, Fusco A, Van den Berghe H \& Bullerdiek J 1998 HMGY is the target of 6p21.3 rearrangements in various benign mesenchymal tumors. Genes, Chromosomes and Cancer 23 279-285.

Kiyokawa H, Kineman RD, Manova-Todorova KO, Soares VC, Hoffman ES, Ono M, Khanam D, Hayday AC, Frohman LA \& Koff A 1996 Enhanced growth of mice lacking the cyclin-dependent kinase inhibitor function of p27(Kip1). Cell 85 721-732.

Korbonits M, Chahal HS, Kaltsas G, Jordan S, Urmanova Y, Khalimova Z, Harris PE, Farrell WE, Claret FX \& Grossman AB 2002 Expression of phosphorylated p27(Kip1) protein and Jun activation domain-binding protein 1 in human pituitary tumors. Journal of Clinical Endocrinology and Metabolism 87 2635-2643.

Lazzerini Denchi E, Attwooll C, Pasini D \& Helin K 2005 Deregulated E2F activity induces hyperplasia and senescence-like features in the mouse pituitary gland. Molecular and Cellular Biology 25 2660-2672.

Lee YS \& Dutta A 2007 The tumor suppressor microRNA let-7 represses the HMGA2 oncogene. Genes and Development 21 1025-1030. 
Lee EY, Cam H, Ziebold U, Rayman JB, Lees JA \& Dynlacht BD 2002 E2F4 loss suppresses tumorigenesis in $\mathrm{Rb}$ mutant mice. Cancer Cell 2 463-472.

Leung SW, Wloga EH, Castro AF, Nguyen T, Bronson RT \& Yamasaki L 2004 A dynamic switch in $\mathrm{Rb}+/-$ mediated neuroendocrine tumorigenesis. Oncogene 23 3296-3307.

Levy A 2002 Physiological implications of pituitary trophic activity. Journal of Endocrinology 174 147-155.

Liau SS, Jazag A, Ito K \& Whang EE 2007 Overexpression of HMGA1 promotes anoikis resistance and constitutive Akt activation in pancreatic adenocarcinoma cells. British Journal of Cancer 96 993-1000.

Lidhar K, Korbonits M, Jordan S, Khalimova Z, Kaltsas G, Lu X, Clayton RN, Jenkins PJ, Monson JP, Besser GM et al. 1999 Low expression of the cell cycle inhibitor p27Kipl in normal corticotroph cells, corticotroph tumors, and malignant pituitary tumors. Journal of Clinical Endocrinology and Metabolism $\mathbf{8 4}$ 3823-3830.

Machiavelli G, Cotignola J, Danilowicz K, Carbonara C, Paes de Lima A, Basso A, Bruno OD \& Szijan I 2008 Expression of p16(INK4A) gene in human pituitary tumours. Pituitary 11 71-75.

Macias E, de Marval PL, Senderowicz A, Cullen J \& Rodriguez-Puebla ML 2008 Expression of CDK4 or CDK2 in mouse oral cavity is retained in adult pituitary with distinct effects on tumorigenesis. Cancer Research 68 162-171.

Magnaghi-Jaulin L, Groisman R, Naguibneva I, Robin P, Lorain S, Le Villain JP, Troalen F, Trouche D \& Harel-Bellan A 1998 Retinoblastoma protein represses transcription by recruiting a histone deacetylase. Nature 391 601-605.

Malumbres M \& Barbacid M 2001 To cycle or not to cycle: a critical decision in cancer. Nature Reviews. Cancer 1 222-231.

Manfioletti G, Giancotti V, Bandiera A, Buratti E, Sautiere P, Cary P, Crane-Robinson C, Coles B \& Goodwin GH 1991 cDNA cloning of the HMGI-C phosphoprotein, a nuclear protein associated with neoplastic and undifferentiated phenotypes. Nucleic Acids Research 19 6793-6797.

Martínez-Balbás MA, Bauer UM, Nielsen SJ, Brehm A \& Kouzarides T 2000 Regulation of E2F1 activity by acetylation. EMBO Journal 19 $662-671$

Mayr C, Hemmann MT \& Bartel DP 2007 Disrupting the pairing between let-7 and Hmga2 enhances oncogenic transformation. Science 315 1576-1579.

Morgan DO 1997 Cyclin-dependent kinases: engines, clocks, and microprocessors. Annual Review of Cell and Development Biology 13 261-291.

Morris DG, Musat M, Czirják S, Hanzély Z, Lillington DM, Korbonits M \& Grossman AB 2005 Differential gene expression in pituitary adenomas by oligonucleotide array analysis. European Journal of Endocrinology 153 143-151.

Nakayama K, Ishida N, Shirane M, Inomata A, Inoue T, Shishido N, Horii I, Loh DY \& Nakayama K 1996 Mice lacking p27(Kip1) display increased body size, multiple organ hyperplasia, retinal dysplasia, and pituitary tumors. Cell 85 707-720.

Neto AG, McCutcheon IE, Vang R, Spencer ML, Zhang W \& Fuller GN 2005 Elevated expression of p21 (WAF1/Cip1) in hormonally active pituitary adenomas. Annals of Diagnostic Pathology 9 6-10.

Nishino J, Kim I, Chada K \& Morrison SJ 2008 Hmga2 promotes neural stem cell self-renewal in young but not old mice by reducing p16Ink4a and p19Arf expression. Cell 135 227-239.

Norbury C \& Nurse P 1992 Animal cell cycles and their control. Annual Review of Biochemistry 61 441-470.

Ogino A, Yoshino A, Katayama Y, Watanabe T, Ota T, Komine C, Yokoyama T \& Fukushima T 2005 The p15(INK4b)/ $\mathrm{p} 16$ (INK4a)/RB1 pathway is frequently deregulated in human pituitary adenomas. Journal of Neuropathology and Experimental Neurology 64 398-403.

Pardee AB 1974 A restriction point for control of normal animal cell proliferation. PNAS 71 1286-1290.
Park MS, Rosai J, Nguyen HT, Capodieci P, Cordon-Cardo C \& Koff A 1999 p27 and $\mathrm{Rb}$ are on overlapping pathways suppressing tumorigenesis in mice. PNAS 96 6382-6387.

Pei L \& Melmed S 1997 Isolation and characterization of a pituitary tumor-transforming gene (PTTG). Molecular Endocrinology 11 433-441.

Pierantoni GM, Finelli P, Valtorta E, Giardino D, Rodeschini O, Esposito F, Losa M, Fusco A \& Larizza L 2005 High-mobility group A2 gene expression is frequently induced in non-functioning pituitary adenomas (NFPAs), even in the absence of chromosome 12 polysomy. Endocrine-Related Cancer 12 867-874.

Pines J \& Hunter T 1989 Isolation of a human cyclin cDNA: evidence for cyclin mRNA and protein regulation in the cell cycle and for interaction with p34cdc2. Cell $\mathbf{5 8} 833-846$.

Qian ZR, Asa SL, Siomi H, Siomi MC, Yoshimoto K, Yamada S, Wang EL, Rahman MM, Inoue H, Itakura M et al. 2009 Overexpression of HMGA2 relates to reduction of the let-7 and its relationship to clinicopathological features in pituitary adenomas. Modern Pathology 22 431-441.

Quereda V \& Malumbres M 2009 Cell cycle control of pituitary development and disease. Journal of Molecular Endocrinology $\mathbf{4 2}$ $75-86$.

Ramsey MR, Krishnamurthy J, Pei XH, Torrice C, Lin W, Carrasco DR, Ligon KL, Xiong Y \& Sharpless NE 2007 Expression of p16Ink4a compensates for p18Ink4c loss in cyclin-dependent kinase 4/6-dependent tumors and tissues. Cancer Research 67 4732-4741.

Rane SG, Cosenza SC, Mettus RV \& Reddy EP 2002 Germ line transmission of the Cdk4(R24C) mutation facilitates tumorigenesis and escape from cellular senescence. Molecular and Cellular Biology 22 644-656.

Reeves R \& Nissen MS 1990 The A.T-DNA-binding domain of mammalian high mobility group I chromosomal proteins. A novel peptide motif for recognizing DNA structure. Journal of Biological Chemistry 265 8573-8582.

Rommel B, Rogalla P, Jox A, Kalle CV, Kazmierczak B, Wolf J \& Bullerdiek J 1997 HMGI-C, a member of the high mobility group family of proteins, is expressed in hematopoietic stem cells and in leukemic cells. Leukemia $\mathcal{E}$ Lymphoma 26 603-607.

Saeger W, Schreiber S \& Lüdecke DK 2001 Cyclins D1 and D3 and topoisomerase II alpha in inactive pituitary adenomas. Endocrine Pathology 12 39-47.

Sasaki F 1988 Changes with age in the number and size of anterior pituitary cells in female mice from suckling to adulthood. Journal of Endocrinology 117 5-10.

Scala S, Portella G, Fedele M, Chiappetta G \& Fusco A 2000 Adenovirus-mediated suppression of HMGI(Y) protein synthesis as potential therapy of human malignant neoplasias. PNAS $\mathbf{9 7}$ $4256-4261$.

Schoenmakers EF, Wanschura S, Mols R, Bullerdiek J, Van den Berghe H \& Van de Ven WJ 1995 Recurrent rearrangements in the high mobility group protein gene, HMGI-C, in benign mesenchymal tumours. Nature Genetics 10 436-444.

Sherr CJ \& Roberts JM 1999 CDK inhibitors: positive and negative regulators of $\mathrm{G}_{1}$-phase progression. Genes and Development 13 1501-1512.

Simpson DJ, Bicknell JE, McNicol AM, Clayton RN \& Farrell WE $1999 a$ Hypermethylation of the p16/CDKN2A/MTSI gene and loss of protein expression is associated with nonfunctional pituitary adenomas but not somatotrophinomas. Genes, Chromosomes and Cancer 24 328-336.

Simpson DJ, Magnay J, Bicknell JE, Barkan AL, McNicol AM, Clayton RN \& Farrell WE 1999b Chromosome 13q deletion mapping in pituitary tumors: infrequent loss of the retinoblastoma susceptibility gene (RB1) locus despite loss of RB1 protein product in somatotrophinomas. Cancer Research $\mathbf{5 9}$ $1562-1566$. 
Simpson DJ, Hibberts NA, McNicol AM, Clayton RN \& Farrell WE 2000 Loss of $\mathrm{pRb}$ expression in pituitary adenomas is associated with methylation of the RB1 CpG island. Cancer Research 60 1211-1216.

Simpson DJ, Frost SJ, Bicknell JE, Broome JC, McNicol AM, Clayton RN \& Farrell WE 2001 Aberrant expression of G(1)/S regulators is a frequent event in sporadic pituitary adenomas. Carcinogenesis 22 $1149-1154$

Sotillo R, Dubus P, Martín J, de la Cueva E, Ortega S, Malumbres M \& Barbacid M 2001 Wide spectrum of tumors in knock-in mice carrying a Cdk4 protein insensitive to INK4 inhibitors. EMBO Journal 20 6637-6647.

Sotillo R, Renner O, Dubus P, Ruiz-Cabello J, Martín-Caballero J, Barbacid M, Carnero A \& Malumbres M 2005 Cooperation between Cdk4 and p2 $7^{\text {kip } 1}$ in tumor development: a preclinical model to evaluate cell cycle inhibitors with therapeutic activity. Cancer Research 65 3846-3852.

Thanos D \& Maniatis T 1995 Virus induction of human IFN beta gene expression requires the assembly of an enhanceosome. Cell $\mathbf{8 3}$ $1091-1100$

Tong Y, Tan Y, Zhou C \& Melmed S 2007 Pituitary tumor transforming gene interacts with $\mathrm{Sp} 1$ to modulate $\mathrm{G}_{1} / \mathrm{S}$ cell phase transition. Oncogene 26 5596-5605.

Turner HE, Nagy Z, Sullivan N, Esiri MM \& Wass JA 2000 Expression analysis of cyclins in pituitary adenomas and the normal pituitary gland. Clinical Endocrinology 53 337-344.

Uhlmann F, Lottspeich F \& Nasmyth K 1999 Sister-chromatid separation at anaphase onset is promoted by cleavage of the cohesin subunit Scc1. Nature 400 37-42.

Vidal A \& Koff A 2000 Cell-cycle inhibitors: three families united by a common cause. Gene 247 1-15.

Wierinckx A, Auger C, Devauchelle P, Reynaud A, Chevallier P, Jan M, Perrin G, Fèvre-Montange M, Rey C, Figarella-Branger D et al. 2007 A diagnostic marker set for invasion, proliferation, and aggressiveness of prolactin pituitary tumors. Endocrine-Related Cancer 14 887-900.

Wölfel T, Hauer M, Schneider J, Serrano M, Wölfel C, Klehmann-Hieb E, De Plaen E, Hankeln T, Meyer zum Büschenfelde KH \& Beach D 1995 A p16 ${ }^{\text {INK4a }}$-insensitive CDK4 mutant targeted by cytolytic T lymphocytes in a human melanoma. Science 269 1281-1284.
Woloschak M, Yu A \& Post KD 1997 Frequent inactivation of the p16 gene in human pituitary tumors by gene methylation. Molecular Carcinogenesis 19 221-224.

Wood LJ, Maher JF, Bunton TE \& Resar LM 2000 The oncogenic properties of the HMG-I gene family. Cancer Research 60 4256-4261.

Xu Y, Sumter TF, Bhattacharya R, Tesfaye A, Fuchs EJ, Wood LJ, Huso DL \& Resar LM 2004 The HMG-I oncogene causes highly penetrant, aggressive lymphoid malignancy in transgenic mice and is overexpressed in human leukemia. Cancer Research 64 3371-3375.

Yamasaki L, Bronson R, Williams BO, Dyson NJ, Harlow E \& Jacks T 1998 Loss of E2F-1 reduces tumorigenesis and extends the lifespan of Rb1 (+ / - ) mice. Nature Genetics 18 360-364.

Yoshino A, Katayama Y, Ogino A, Watanabe T, Yachi K, Ohta T, Komine C, Yokoyama T \& Fukushima T 2007 Promoter hypermethylation profile of cell cycle regulator genes in pituitary adenomas. Journal of Neuro-Oncology 83 153-162.

Zaidi MR, Okada Y \& Chada KK 2006 Misexpression of full-length HMGA2 induces benign mesenchymal tumors in mice. Cancer Research 66 7453-7459.

Zhang X, Horwitz GA, Heaney AP, Nakashima M, Prezant TR, Bronstein MD \& Melmed S 1999 Pituitary tumor transforming gene (PTTG) expression in pituitary adenomas. Journal of Clinical Endocrinology and Metabolism 84 761-767.

Zhou X, Benson KF, Ashar HR \& Chada K 1995 Mutation responsible for the mouse pygmy phenotype in the developmentally regulated factor HMGI-C. Nature 376 771-774.

Zhu X, Mao X, Hurren R, Schimmer AD, Ezzat S \& Asa SL 2008 Deoxyribonucleic acid methyltransferase $3 \mathrm{~B}$ promotes epigenetic silencing through histone 3 chromatin modifications in pituitary cells. Journal of Clinical Endocrinology and Metabolism 93 3610-3617.

Zou H, McGarry TJ, Bernal T \& Kirschner MW 1999 Identification of a vertebrate sister-chromatid separation inhibitor involved in transformation and tumorigenesis. Science 285 418-422.

Received in final form 25 February 2010

Accepted 10 March 2010

Made available online as an Accepted

Preprint 10 March 2010 